\title{
NITRATE REDUCTASE ACTIVITY IN LEAVES AND STEMS OF TANNER GRASS (Brachiaria radicans Napper)
}

\author{
Jairo Osvaldo Cazetta ${ }^{*}$; Luciana Cristine Vasques Villela ${ }^{1}$ \\ UNESP/FCAV - Depto. de Tecnologia - Via de Acesso Prof. Paulo Donato Castellane s/n, 14884-900 - Jaboticabal, \\ SP - Brasil. \\ *Corresponding author 〈cazetta@fcav.unesp.br>
}

\begin{abstract}
Tanner grass (Brachiaria radicans Napper) is a forage plant that is adapted to well-drained soils or wetlands, and responds well to nitrogen $(\mathrm{N})$ fertilization. The assimilation of $\mathrm{N}$ involves the nitrate reductase (NR) enzyme, and its activity seems to be dependent on $\mathrm{N}$ supply. Molybdenum (Mo) is also important because it is a cofactor of NR. In this study, the variables of an in vivo assay were optimized for measuring nitrate reductase activity (NRA) in the leaves and stem tissues. This method was used to evaluate $\mathrm{NO}_{3}$ metabolism in plants fertilized with $\mathrm{NaNO}_{3}, \mathrm{NH}_{4} \mathrm{Cl}$ or urea, in association with or without application of $\mathrm{H}_{2} \mathrm{MoO}_{4}$, aiming to provide guidelines for $\mathrm{N}$ management of this species. The best conditions to determine NRA involved the incubation of $300 \mathrm{mg}$ of tissues in a medium composed of $200 \mathrm{mmol} \mathrm{dm}^{-3}$ phosphate buffer ( $\mathrm{pH} 7.4$ ), $60 \mathrm{mmol} \mathrm{dm}^{-3} \mathrm{KNO}_{3}, 10 \mathrm{~cm}^{3} \mathrm{dm}^{-3} \mathrm{n}$-butanol, $0.1 \mathrm{~cm}^{3} \mathrm{dm}^{-3}$ detergent (triton-X-100 ${ }^{\circledR}$ ), under vacuum and in the dark for a period of 60 to 100 minutes. Leaves showed NRA levels two to three times higher than stems. Although there were some interactions between treatments, stem fresh weight and NRA were not affected by $\mathrm{N}$ sources. Plants fertilized with $\mathrm{NaNO}_{3}$ showed the best growth and NRA values when compared with $\mathrm{NH}_{4} \mathrm{Cl}$ and urea, which had, respectively, the lowest and intermediate scores. The application of Mo in the absence of $\mathrm{N}$ improved NRA and did not affect leaf and stalk growth. In the presence of N, the Mo levels applied limited leaf NRA and plant development.
\end{abstract}

Key words: Brachiaria arrecta, nitrogen, molybdenum, enzyme

\section{ATIVIDADE DA REDUTASE DO NITRATO EM FOLHAS E CAULES DE 'TANNER GRASS'(Brachiaria radicans Napper)}

\begin{abstract}
RESUMO: A 'tanner grass' (Brachiaria radicans Napper) é uma planta forrageira que se adapta bem tanto em solos bem drenados como em encharcados, e responde bem à adubação nitrogenada. A assimilação do nitrogênio (N) envolve a enzima nitratro redutase (NR) cuja atividade é dependente do suprimento de N. O Molibdênio (Mo) também é importante por ser um co-fator da RN. Neste trabalho foi otimizado um procedimento para a determinação da atividade da redutase do nitrato (NRA) in vivo para tecidos de folha $\mathrm{e}$ caule. Este método foi aplicado para avaliar plantas fertilizadas com $\mathrm{NaNO}_{3}, \mathrm{NH}_{4} \mathrm{Cl}$ ou uréia, com e sem a aplicação de $\mathrm{H}_{2} \mathrm{MoO}_{4}$, visando contribuir no balizamento da adubação nitrogenada para esta espécie. As melhores condições para a determinação da NRA foram: incubação de $300 \mathrm{mg}$ de tecidos em um meio composto por tampão fosfato $200 \mathrm{mmol} \mathrm{dm}{ }^{-3}(\mathrm{pH} 7,4) ; \mathrm{KNO}_{3} 60 \mathrm{mmol} \mathrm{dm}{ }^{-3}$; n-butanol $10 \mathrm{~cm}^{3} \mathrm{dm}^{-3}$; triton-x- $100^{\oplus} 0,1$ $\mathrm{cm}^{3} \mathrm{dm}^{-3}$; infiltração a vácuo no escuro; por período de 60 a 100 minutos. As folhas apresentaram NRA duas a três vezes maior que os caules. A matéria fresca do caule e a NRA não foi afetada pelas fontes de N. As plantas adubadas com $\mathrm{NaNO}_{3}, \mathrm{NH}_{4} \mathrm{Cl}$ e uréia apresentaram, respectivamente, os maiores, os menores e intermediários crescimento e NRA. A aplicação de Mo na ausência de $\mathrm{N}$ aumentou a NRA e não afetou o crescimento, mas, na presença de N, limitou a NRA nas folhas e o crescimento das plantas.

Palavras-chave: Brachiaria arrecta, nitrogênio, molibdênio, enzima
\end{abstract}

\section{INTRODUCTION}

Tanner grass is the common name for Brachiaria radicans Napper (Skerman \& Riveros, 1990), lately described as Brachiaria arrecta (Souza, 1999). This forage grass is very competitive when compared with other forage species, and grows well under tropical conditions (Mitidieri, 1983; Skerman \& Riveros, 1990). As in the majority of crops, nitrogen $(\mathrm{N})$ is one of the most important nutrients in grasses. To improve the efficiency of $\mathrm{N}$ fertilization, more information on the processes of $\mathrm{N}$ utilization is required for each plant species (Baer \& Collet, 1981). There is evidence suggesting that nitrate reductase activity (NRA) is the main limiting step in $\mathrm{N}$ assimilation in most plants (Srivastava, 1990; Lea, 1997). Leaf NRA seems to be dependent on the source of N (Roberts \& Menary, 1994), and on a continuous supply of nitrate $\left(\mathrm{NO}_{3}{ }^{-}\right)$through the xylem (Barthes et al., 1996; Kawachi et al., 2002). Molybdenum (Mo) is also important because it is a cofactor of NR (Lea, 1997). Thus, some interac- 
tions between the effects of $\mathrm{N}$ sources and Mo fertilization on NRA have been reported (Dordas et al., 2001). The NRA levels in a plant are of help in the study of plant metabolism and its complex relationship with the environment (Muller \& Janieshch, 1993; Faleiros \& Cazetta, 1996; Viégas et al., 1999; Stolz \& Bazu, 2002), and one of the challenges of research in $\mathrm{N}$ metabolism is to develop approaches to analyze this complex interaction (Stitt et al., 2002).

NRA can be measured by either an in vivo or in vitro assay (Viégas et al., 1999). The in vitro assay is accomplished by extracting the enzymatic fraction from the tissue (Lillo, 1983; Viégas et al., 1999), and by measuring the reaction in an appropriate buffered medium (Aslam et al., 1984; Lillo, 1983). On the other hand, the in vivo assay can be carried out easily, without enzyme extraction, by incubating tissue samples in a buffered medium containing $\mathrm{NO}_{3}^{-}$, solvent and/or detergent, and by measuring $\mathrm{NO}_{2}^{-}$produced during an adequate period of time, in the dark (Jaworski, 1971; Jones $\&$ Sheard, 1977; Harper, 1981). Nitrite production in the in vivo assay depends on the diffusion of $\mathrm{NO}_{3}{ }^{-}$into the tissue, to reach the cytoplasm of cells where the enzyme is located. Therein, nitrate reductase catalyses the conversion of $\mathrm{NO}_{3}^{-}$to $\mathrm{NO}_{2}^{-}$, by using the reducing power of NADH (Nicotinamide Adenine Dinucleotide, reduced form) coming from the respiratory oxidative pathways. Under normal conditions, $\mathrm{NO}_{2}^{-}$produced in green tissues is transported into chloroplasts and reduced to ammonia, using the reducing power of reduced ferredoxin, derived from photosynthetic electron transport (Lea, 1997). However, during the in vivo assay procedure, the tissue is kept in the dark, which inhibits $\mathrm{NO}_{2}^{-}$reduction. This leads to $\mathrm{NO}_{2}^{-}$accumulation, which drives its diffusion from the tissue toward the incubation medium, where it is measured as the product of NR activity. Thus, $\mathrm{NO}_{2}^{-}$present in the medium not only depends on the NRA, but also on the diffusion processes.

Although NR always catalyzes the same reaction, its location within tissues, structure, and regulatory mechanisms are organism-dependent (Stolz \& Bazu, 2002). Due to differences between species, or even between various plant parts, it is best to optimize the conditions for the in vivo assay, before NRA determinations are made (Lin \& Kao, 1980; Faleiros \& Cazetta, 1996). Therefore, the first objective of this research was to establish the optimum conditions for tanner grass leaf and stem NRA determinations, using the in vivo assay method. The second objective was to evaluate NRA in leaves and stems of tanner grass plants fertilized with $\mathrm{NaNO}_{3}$, $\mathrm{NH}_{4} \mathrm{Cl}$, or urea, with or without Mo, for the purpose of providing guidelines for $\mathrm{N}$ management of this species in the future.

\section{MATERIAL AND METHODS}

Plants were collected in Jaboticabal-SP, Brazil $\left(21^{\circ} 15^{\prime} 17^{\prime}\right.$ 'S and $48^{\circ} 19^{\prime} 20^{\prime}$ ' $\left.\mathrm{W}\right)$, in December of 2002 , and separated into leaf blades and stems (stalk plus leaf sheath adhering to the stalk). The central portion of leaves was cut into discs with a diameter of $1.0 \mathrm{~cm}$. The stems were cut transversally into $2 \mathrm{~mm}$ long pieces. Both tissues were assayed for their in vivo NRA. The basal assay procedure used was a modification of the Jaworski (1971) method, described by Faleiros \& Cazetta (1996), based on the incubation of fresh tissue $(300 \mathrm{mg}$ ) in 10.0 $\mathrm{cm}^{3}$ of a medium containing $25 \mathrm{mmol} \mathrm{dm}{ }^{-3}$ phosphate buffer (pH 7.2), $25 \mathrm{mmol} \mathrm{dm}^{-3} \mathrm{KNO}_{3}, 30 \mathrm{~cm}^{3} \mathrm{dm}^{-3}$ n-propanol, and $30 \mathrm{~cm}^{3} \mathrm{dm}^{-3}$ of triton X-100 (t-octyl-phenoxypolyethoxy-ethanol, Rohm \& Haas Co: U.S.A.). In order to induce anaerobic conditions in the incubation medium, the system was subjected to vacuum infiltration three times, as recommended by Klepper et al. (1971) to remove air from the tissue. The medium was maintained in the dark at $30^{\circ} \mathrm{C}$ for 60 minutes.

The $\mathrm{NO}_{2}^{-}$produced by action of the NR enzyme was determined by drawing an $0.5 \mathrm{~cm}^{3}$ aliquot of the incubation medium, and treating this sample with 0.5 $\mathrm{cm}^{3}$ of $10 \mathrm{~g} \mathrm{dm}^{-3}$ sulfanilamide in $3 \mathrm{~mol} \mathrm{dm}^{-3} \mathrm{HCl}$ and $0.5 \mathrm{~cm}^{3}$ of $0.2 \mathrm{~g} \mathrm{dm}^{-3} \mathrm{~N}$-(1-naphtyl)-ethylenediamine dihydrochloride. After 20 minutes, the solution was diluted to $4.5 \mathrm{~cm}^{3}$ with deionized water, and the absorbance $(540 \mathrm{~nm})$ was measured using an Ultrospec $2000^{\circledR}$ spectrophotometer (Pharmacia Biotech: England). In order to calculate the amount of $\mathrm{NO}_{2}^{-}$contained in the sample, a standard curve was prepared in the same way as the sample, but using aliquots of $0.5 \mathrm{~cm}^{3}$ of $\mathrm{NaNO}_{2}$ standard solutions (containing from 0 to $140 \mu \mathrm{mol} \mathrm{dm}{ }^{-3}$ $\mathrm{NO}_{2}^{-}$).

The optimization of the NRA assay was developed by evaluating the best incubation time (ranging from 20 to 120 minutes), $\mathrm{pH}$ level (6.0 to 8.0), surfactant compounds (solvents: ethanol, n-propanol, n-butanol, ketone, ethyl acetate; and detergents: triton $\mathrm{X}-100^{\circledast}$ or tween $80^{\circledR}$ (poly-oxy-ethylene sorbitan monooleate, Atlas Chemie: Germany), as well as the best concentration for phosphate (ranging from 0 to $400 \mathrm{mmol} \mathrm{dm}^{-3}$ ), $\mathrm{NO}_{3}^{-}$(0 to $100 \mathrm{mmol}$ $\left.\mathrm{dm}^{-3}\right)$, solvent $\left(0\right.$ to $\left.100 \mathrm{~cm}^{3} \mathrm{dm}^{-3}\right)$, and surfactant $(0$ to $100 \mathrm{~g} \mathrm{dm}^{-3}$ ), for the incubation medium. The effect of vacuum infiltration on the performance of the assay was also studied. The $\mathrm{NO}_{2}^{-}$diffusion results were expressed as micromoles of $\mathrm{NO}_{2}^{-}$per gram of fresh tissue, after a given incubation time, and NRA results were expressed as micromoles of $\mathrm{NO}_{2}^{-}$produced per $\mathrm{g}$ of fresh tissue per hour $\left(\mu \mathrm{mol} \mathrm{g} \mathrm{g}^{-1} \mathrm{~h}^{-1} \mathrm{NO}_{2}^{-}\right)$.

The optimized NRA method was applied to study $\mathrm{NO}_{3}^{-}$assimilation in stems and leaves of tanner grass plants fertilized with different sources of $\mathrm{N}$, and varying levels of Mo. This experiment was carried out using a 
medium-textured Typic Hapludox, collected from a field previously cultivated with corn (Zea mays L.). The initial soil properties were: $\mathrm{pH}$ in $0.01 \mathrm{~mol} \mathrm{~L} \mathrm{CaCl}_{2}$ solution $=4.7$; organic matter $=12 \mathrm{~g} \mathrm{dm}^{-3} ; \mathrm{P}=11.0 \mathrm{mg} \mathrm{dm}^{-3}$; $\mathrm{K}=1.5 \mathrm{mmol}_{\mathrm{c}} \mathrm{dm}^{-3} ; \mathrm{Ca}=16.0 \mathrm{mmol}_{\mathrm{c}} \mathrm{dm}^{-3} ; \mathrm{Mg}=5.0$ mmol $\mathrm{dm}^{-3} ; \mathrm{H}^{\mathrm{c}}+\mathrm{Al}^{3+}=37.0 \mathrm{mmol}_{\mathrm{c}} \mathrm{dm}^{-3^{\mathrm{c}}}$, cation exchange capacity $($ CEC $)=59.5$, and base saturation $=37.8 \%$. To reduce acidity, $\mathrm{CaO}$ was added and blended into the soil at a rate necessary to obtain a base saturation of $60 \%$. The mixture was kept moist, and let stand for 15 days. The soil was then fertilized with $\mathrm{Ca}\left(\mathrm{H}_{2} \mathrm{PO}_{4}\right)_{2}, \mathrm{~K}_{2} \mathrm{SO}_{4}$, and $\mathrm{Mg}\left(\mathrm{SO}_{4}\right)_{2}$, at levels corresponding to $80 \mathrm{~kg} \mathrm{ha}^{-1} \mathrm{P}_{2} \mathrm{O}_{5}, 60$ $\mathrm{kg} \mathrm{ha}^{-1} \mathrm{~K}_{2} \mathrm{O}$, and $30 \mathrm{~kg} \mathrm{ha}^{-1} \mathrm{Mg}$, respectively, and then transferred to $5 \mathrm{dm}^{3}$ pots. Rooted sprouts of tanner grass of similar size were collected from the field, and individually planted in 32 pots.

The eight treatments consisted of three sources of $\mathrm{N}$ : $\mathrm{NaNO}_{3}, \mathrm{NH}_{4} \mathrm{Cl}$, and urea. All $\mathrm{N}$ sources were applied at a rate corresponding to $300 \mathrm{~kg} \mathrm{~N} \mathrm{ha}^{-1}$, combined with two levels of Mo fertilization ( 0 and $20 \mathrm{~kg} \mathrm{Mo} \mathrm{ha}^{-1}$, as $\mathrm{H}_{2} \mathrm{MoO}_{4}$ ), plus two control treatments: no $\mathrm{N}$ or Mo fertilization, and fertilization with Mo, applied without $\mathrm{N}$. The Mo fertilizer was added to appropriate treatments before planting. The different sources of $\mathrm{N}$ were applied with the irrigation water, divided into four weekly applications, which were started 10 days after planting.

The experiment was organized as a completely randomized design, with eight treatments and four replications, where each $5 \mathrm{dm}^{3}$ pot containing one plant comprised an individual experimental unit. Plants were maintained in a growth chamber with a photoperiod of $16 \mathrm{~h}$ $\left(176 \mu \mathrm{mol}\right.$ PPFD $\left.\mathrm{m}^{-2} \mathrm{~s}^{-1}\right)$ provided by incandescent and fluorescent bulbs. The temperature was maintained between 20 and $35^{\circ} \mathrm{C}$ (night and day, respectively) and the experiment was conducted for 40 days after planting. Plants were then harvested and separated into stems (stalk plus sheath adhering to stalk) and leaf blades and weighed, and NRA determinations were made according to the method previously described.

A factorial design (three $\mathrm{N}$ sources $\times$ two Mo levels, plus two controls), with four replications, was used for statistical analysis in this study. The F test was applied to detect main and interaction effects, and means were compared using Tukey test $(P<0.05)$. Analyses of variance and factorial analyses were performed using SAS $^{\circledR}$ (SAS version 6.11 software package, Statistical Analysis System Institute: U.S.A).

\section{RESULTS AND DISCUSSION}

Results obtained for the standard curve (Figure 1) showed high correlation $\left(r^{2}=0.999\right)$ between absorbance at $540 \mathrm{~nm}$ and $\left[\mathrm{NO}_{2}^{-}\right]$. This indicates that the assay model was reliable to determine $\mathrm{NO}_{2}^{-}$with good precision.
Stem NRA showed some variations within the first 60 minutes of incubation, but tended to be stable from 60 to 120 minutes (Figure 2), and exhibited an activity of about $20 \%$ of that observed for leaves.

NRA results for leaves revealed an increase $(P<0.05)$ during incubation times from 20 to $120 \mathrm{~min}-$ utes (Figure 2). The behavior of NRA during incubation was reported to increase (Jaworski, 1971; Streeter \& Bosler, 1972; Blondel \& Blanc, 1975; Lin \& Kao, 1980; Faleiros \& Cazetta, 1996), to remain constant up to 120 minutes (Brunnetti \& Hageman, 1976, Heuer \& Plaut, 1978), to decrease during the first 60 minutes (Streeter $\&$ Bosler, 1972), or to decrease after 60 minutes (Klepper et al., 1971), indicating that it is dependent upon the species or tissue under study. In order to be reduced to $\mathrm{NO}_{2}^{-}$ in the in vivo assay, $\mathrm{NO}_{3}^{-}$has to diffuse into the tissue

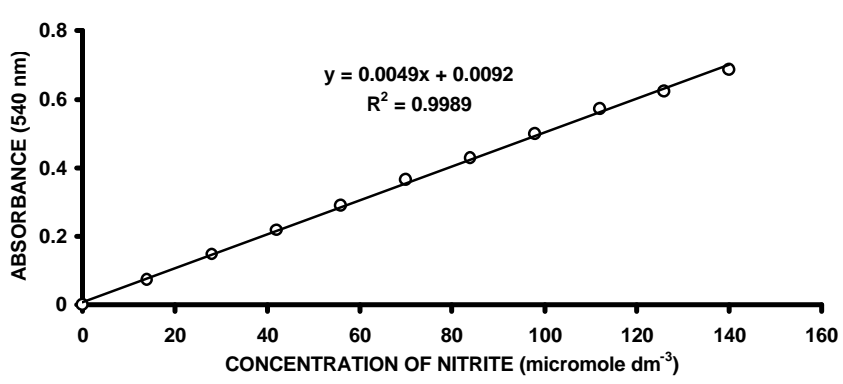

Figure 1- Standard curve obtained by reacting $0.5 \mathrm{~cm}^{3}$ of $\mathrm{NaNO}_{2}$ standard solutions (containing 0 to $140 \mu$ mole $\mathrm{NO}_{2}^{-} \mathrm{dm}^{-3}$ ) with $0.5 \mathrm{~cm}^{3}$ of $10 \mathrm{~cm}^{3} \mathrm{dm}^{-3}$ sulfanilamide in $3 \mathrm{~mol} \mathrm{dm}^{-3}$ $\mathrm{HCl}$, and $0.5 \mathrm{~cm}^{3}$ of $0.2 \mathrm{~cm}^{3} \mathrm{dm}^{-3} \mathrm{~N}$-(1-naphtyl)ethylenediamine dihydrocloride, and after 20 minutes diluted to $4.5 \mathrm{~cm}^{3}$ with deionized water. Each point in the graph refers to means obtained from triplicates.

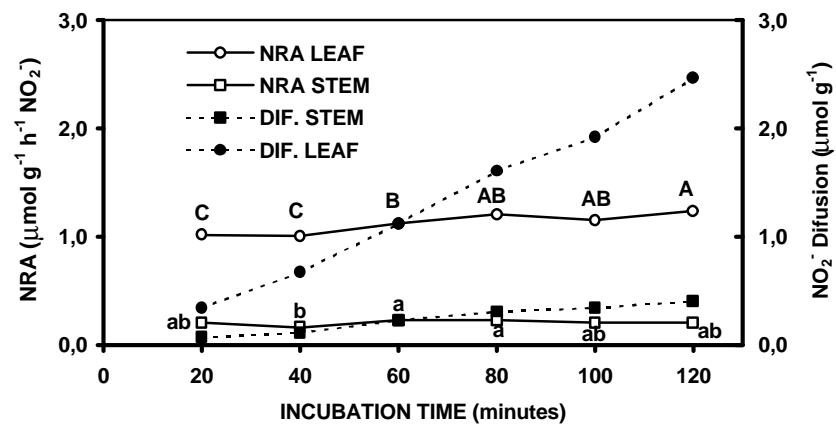

Figure 2 - Nitrite diffused from leaf (DIF. LEAF) and stem (DIF. STEM) tissues of Brachiaria radicans into incubation medium (25 mmol dm${ }^{-3}$ Phosphate buffer, $\mathrm{pH} \mathrm{7.2,} 25$ mmol dm ${ }^{-3} \mathrm{KNO}_{3}, 30 \mathrm{~cm}^{3} \mathrm{dm}^{-3} \mathrm{n}$-propanol and $30 \mathrm{~cm}^{3}$ $\mathrm{dm}^{-3}$ triton- $\mathrm{X}-100^{\circledR}$, at $30^{\circ} \mathrm{C}$ after vacuum infiltration), as well as nitrate reductase activity for leaf (NRA LEAF) and stem (NRA STEM), obtained after different incubation time periods. Means (obtained from triplicates and represented as points on the graph) for a given line with the same letter are not different (Tukey test, $P<0.05)$. 
and the $\mathrm{NO}_{2}$ produced has to diffuse into the incubation medium in order to be measured. Thus, since induced NRA is not expected to increase during incubation, increases suggest that variations may rely on diffusion processes. This possibility reinforced the need for solvents and surfactants as medium components.

The inclusion of n-butanol or n-propanol in the leaf incubation medium promoted higher NRA, when compared to the addition of ethanol. Acetone and ethyl acetate suggested intermediate promotion (Figure 3). Among the surfactants, triton-X-100 ${ }^{\circledR}$ improved NRA, in comparison to tween- $80^{\circledR}$ (Figure 3 ). When these same chemicals were included in the incubation medium for stem tissue, no differences $(P>0.05)$ were observed (Figure 3). The inclusion of solvents in the incubation medium was intended to increase membrane permeability. This would facilitate the influx of $\mathrm{NO}_{3}^{-}$into tissue cells, and $\mathrm{NO}_{2}^{-}$efflux into the medium. For triticale (Triticosecale Wittmack) propanol was more effective than butanol (Lin \& Kao, 1980), but for tanner grass similar results were obtained for both alcohols (Figure 3). Butanol was chosen because of its supposedly lower toxicity and higher water solubility, compared to propanol (Jaworski, 1971).

The presence of a detergent in the medium is important in order to minimize liquid surface tensions, and improve contact of the tissue with the medium. However, our data indicated that NRA decreased when triton-X$100^{\circledR}$ was added to the medium (Figure 4). By increasing the concentrations of the triton- $\mathrm{X}-100^{\circledR}$ detergent from 0 to $100 \mathrm{~cm}^{3} \mathrm{dm}^{-3}$ in the incubation medium, leaf NRA decreased by an average of $5.8 \%$ for each $10 \mathrm{~cm}^{3} \mathrm{dm}^{-3}$ increment of triton-X-100 ${ }^{\circledR}$ added. Stem tissue NRA decreased by an average of $47 \%$ when the triton- $\mathrm{X}-100^{\circledR}$ concentration in the medium was increased from $0 \mathrm{~cm}^{3}$ $\mathrm{dm}^{-3}$ to $30 \mathrm{~cm}^{3} \mathrm{dm}^{-3}$. Higher concentrations tended to in-

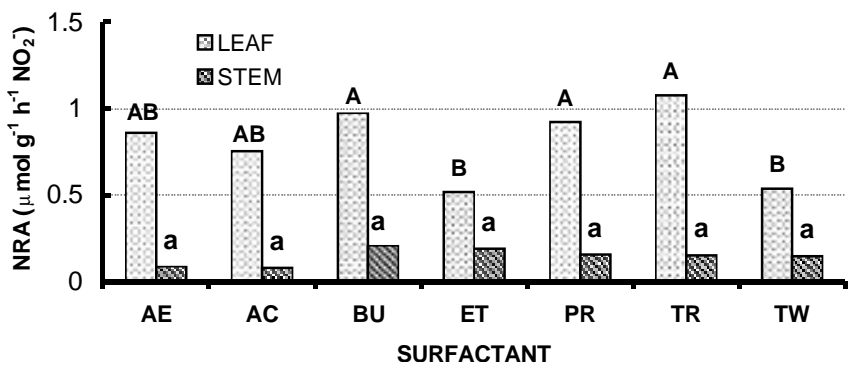

Figure 3 - Nitrate reductase activity (NRA) determined in leaf and stem tissues of Brachiaria radicans incubated for 80 minutes in media ( $25 \mathrm{mmol} \mathrm{dm}^{-3}$ Phosphate buffer, $\mathrm{pH}$ 7.2; $25 \mathrm{mmol} \mathrm{dm}^{-3} \mathrm{KNO}_{3}$, at $30^{\circ} \mathrm{C}$ under vacuum), with different surfactant compounds (AE, ethyl acetate; $\mathrm{AC}$, acetone; BU, butanol; ET, ethanol; PR, propanol; TR, triton-X-100 ${ }^{\circledR}$; TW, tween- $80^{\circledR}$ ). Means (obtained from triplicate samples and represented as bars on the graph) for a given tissue with the same letter are not different (Tukey test, $P<0.05$ ). duce further reductions, but at much smaller rates (Figure 4). These results suggest that triton- $X-100^{\circledR}$ could be excluded from the incubation medium for both tissues. Nevertheless, considering that the concentration required to reduce liquid tension is very low (about $0.1 \mathrm{~cm}^{3} \mathrm{dm}^{-3}$ ), and also that a mixture of surfactants tend to induce a synergistic effect (Streeter \& Bosler, 1972; Tingey et al., 1974; Lawrence \& Herrick, 1982; Faleiros \& Cazetta, 1996), it would be advisable to include $0.1 \mathrm{~cm}^{3} \mathrm{dm}^{-3}$ triton-X-100 ${ }^{\circledR}$.

After choosing n-butanol as the solvent to be used, the effect of different concentrations in the medium was observed. Increasing the concentration from $0 \mathrm{~cm}^{3} \mathrm{dm}^{-3}$ to $10 \mathrm{~cm}^{3} \mathrm{dm}^{-3}$ increased NRA by an average of $5 \%$ for leaf, and $18 \%$ for stem tissue, while concentrations higher than $10 \mathrm{~cm}^{3} \mathrm{dm}^{-3}$ decreased NRA. The inhibitory effect was proportional to the concentration of butanol, chiefly in the range from $10 \mathrm{~cm}^{3} \mathrm{dm}^{-3}$ to 70 $\mathrm{cm}^{3} \mathrm{dm}^{-3}$ for leaf, and from $10 \mathrm{~cm}^{3} \mathrm{dm}^{-3}$ to $30 \mathrm{~cm}^{3} \mathrm{dm}^{-3}$ for stem tissues. Comparing the results of butanol at 10 $\mathrm{cm}^{3} \mathrm{dm}^{-3}$ with butanol at $100 \mathrm{~cm}^{3} \mathrm{dm}^{-3}$, NRA was reduced by $93 \%$ and $89 \%$ for leaf and stem tissues, respectively (Figure 5).

In spite of the fact that data from the different tests were obtained on different dates, and with the use of different plants, it becomes clear that when the average values for NRA are compared, the lower activities observed in the first tests (Figure 2,3) were mainly due to the use of excessive concentrations of surfactants $\left(30 \mathrm{~cm}^{3} \mathrm{dm}^{-3}\right)$. The best butanol concentration $\left(30 \mathrm{~cm}^{3} \mathrm{dm}^{-3}\right)$ for Cajanus cajan (Faleiros \& Cazetta, 1996) promoted a significant inhibitory effect when applied to tanner grass.

Nitrate reductase activity was enhanced by increases in $\mathrm{NO}_{3}^{-}$supply from $0 \mathrm{mmol} \mathrm{dm}{ }^{-3}$ to $33 \mathrm{mmol}$ $\mathrm{dm}^{-3}$, while no further effect was observed for $\left[\mathrm{NO}_{3}{ }^{-}\right]$ higher than $33 \mathrm{mmol} \mathrm{dm}^{-3}$, for either leaf or stem tissues,

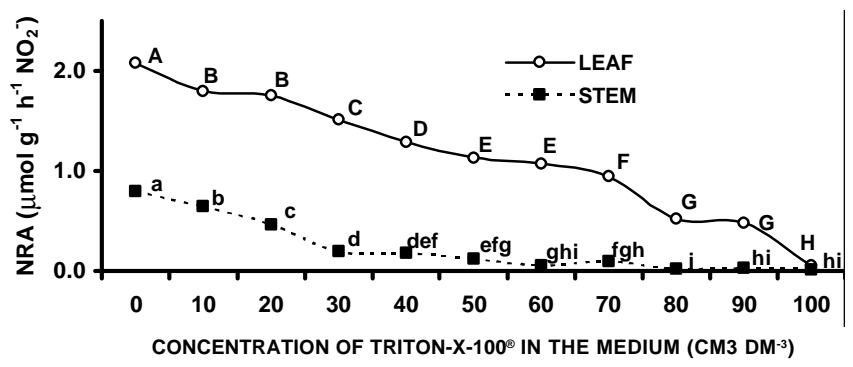

Figure 4 - Nitrate reductase activity (NRA) determined in leaf and stem tissues of Brachiaria radicans incubated for 80 minutes in media $\left(25 \mathrm{mmol} \mathrm{dm}{ }^{-3}\right.$ phosphate buffer, $\mathrm{pH}$ $7.2,25 \mathrm{mmol} \mathrm{dm}^{-3} \mathrm{KNO}_{3}, 30 \mathrm{~cm}^{3} \mathrm{dm}^{-3} \mathrm{n}$-butanol, at $30^{\circ} \mathrm{C}$ under vacuum), with different triton-X-100 ${ }^{\circledR}$ concentrations $\left(\mathrm{cm}^{3} \mathrm{dm}^{-3}\right)$. Means (obtained from triplicates and represented as points on the graph) comprising a given line with the same letter are not different (Tukey test, $P<0.05$ ). 
indicating that the optimum concentration should be between $17 \mathrm{mmol} \mathrm{dm}^{-3}$ and $33 \mathrm{mmol} \mathrm{dm}^{-3}$ (Figure 6). Media containing $\left[\mathrm{NO}_{3}^{-}\right.$] higher than $83 \mathrm{mmol} \mathrm{dm}^{-3}$ promoted a decreased NRA in stem tissue. These findings agree with data from previous studies (Nicholas et al., 1976; Watanabe et al., 1985; Faleiros \& Cazetta, 1996), which showed that high $\left[\mathrm{NO}_{3}^{-}\right]$could decrease enzyme activity. However, in this research, leaves did not exhibit a decrease in NRA, even when $\left[\mathrm{NO}_{3}{ }^{-}\right]$was increased to 100 mmol $\mathrm{dm}^{-3}$. This suggests that tanner grass leaves tolerated a wider range of $\left[\mathrm{NO}_{3}^{-}\right]$than did other plants (Nicholas et al., 1976; Faleiros \& Cazetta, 1996). These results confirm that the addition of exogenous $\mathrm{NO}_{3}^{-}(60 \mathrm{mmol}$ $\mathrm{dm}^{-3}$ ) is necessary in order to ensure maximum NRA during an in vivo assay of tanner grass tissues. This also indicates that concentrations of about $60 \mathrm{mmol} \mathrm{dm}^{-3}$ are sufficient to saturate the enzyme in in vivo assays for both tissues analyzed.

The highest values were obtained when leaf and stem tissues were incubated in media containing phosphate buffer at concentrations of $200 \mathrm{mmol} \mathrm{dm}^{-3}$ and 300



Figure 5 - Nitrate reductase activity (NRA) determined in leaf and stem tissues of Brachiaria radicans incubated for 80 minutes in media $\left(25 \mathrm{mmol} \mathrm{dm}^{-3}\right.$ Phosphate buffer, $\mathrm{pH}$ 7.2; $25 \mathrm{mmol} \mathrm{dm}^{-3} \mathrm{KNO}_{3}, 0.1 \mathrm{~cm}^{3} \mathrm{dm}^{-3}$ triton-X-100 ${ }^{\circledR}$, at $30{ }^{\circ} \mathrm{C}$ under vacuum), with different butanol concentrations $\left(\mathrm{cm}^{3} \mathrm{dm}^{-3}\right)$. Means (obtained from triplicates and represented as points on the graph) for a given line with the same letter are not different (Tukey test, $P<0.05)$.

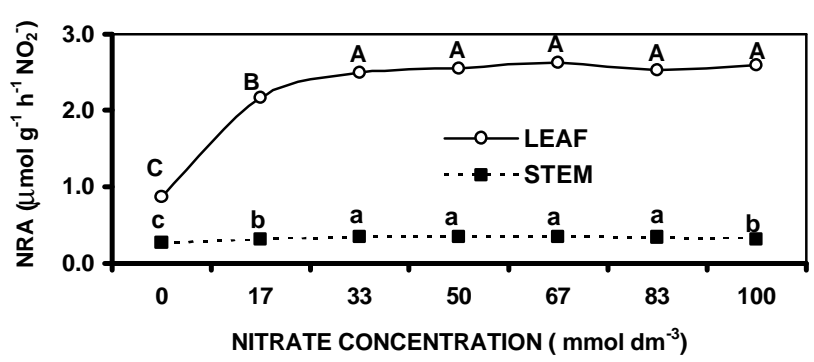

Figure 6 - Nitrate reductase activity (NRA) determined in leaf and stem tissues of Brachiaria radicans incubated for 80 minutes in media $\left(200 \mathrm{mmol} \mathrm{dm}^{-3}\right.$ phosphate buffer $\mathrm{pH}$ 7.4; $10 \mathrm{~cm}^{3} \mathrm{dm}^{-3} \mathrm{n}$-butanol and $0.1 \mathrm{~cm}^{3} \mathrm{dm}^{-3}$ triton-X$100^{\circledR}$, at $30^{\circ} \mathrm{C}$ under vacuum) with different $\mathrm{NO}_{3}^{-}$ concentrations. Means (obtained from triplicates and represented as points on the graph) for a given line with the same letter are not different (Tukey test, $P<0.05$ ). mmol dm ${ }^{-3}$, respectively (Figure 7). A significant $(P<0.05)$ effect of the $\left[\mathrm{PO}_{4}^{-3}\right]$ concentration in the medium on NRA was observed for tanner grass, but not for other species (Jones \& Sheard, 1977; Nicholas et al., 1976; Streeter \& Bosler, 1972).

Leaf NRA was enhanced when $\mathrm{pH}$ increased from 6.0 to 7.6, but dropped when $\mathrm{pH}$ further increased from 7.6 to 8.0. Nitrate reductase activity for $\mathrm{pH} 7.2$ and 7.6 did not differ $(P>0.05)$, indicating that the optimum $\mathrm{pH}$ for the incubation medium may be between those values. For stems, probably due to the low levels of NRA in this tissue, no difference $(P>0.05)$ was detected for $\mathrm{pH}$ ranging from 6.8 to 8.0 (Figure 8), even though the behavior of NRA as a function of $\mathrm{pH}$ was similar to that observed for leaves. These results show similar patterns to those found for soybean (Glycine max L. Merril), beans (Phaseolus vulgaris L.), and pigeon pea (Cajanus cajan L. Millsp) (Jaworski, 1971; Nicholas et al., 1976; Puranik \& Srivastava, 1983; Faleiros \& Cazetta, 1996), while different values were observed for triticale (Triticosecale Wittmack) (Lin \& Kao, 1980).

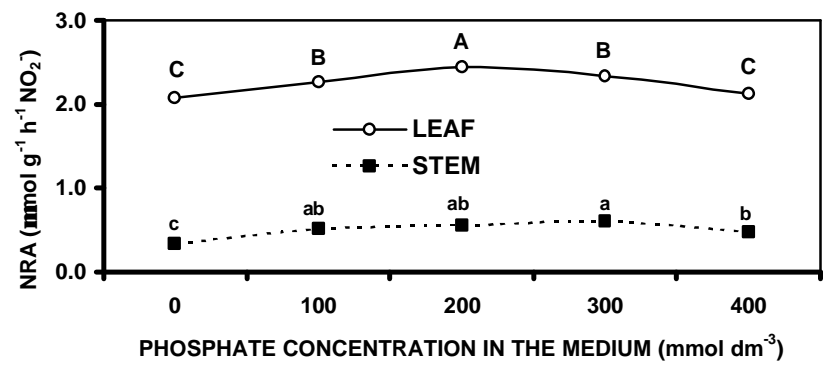

Figure 7 - Nitrate reductase activity (NRA) determined in leaf and stem tissues of Brachiaria radicans incubated for 80 minutes in media (phosphate buffer $\mathrm{pH} \mathrm{7.2;60} \mathrm{mmol}$ $\mathrm{dm}^{-3} \mathrm{KNO}_{3}, 10 \mathrm{~cm}^{3} \mathrm{dm}^{-3} \mathrm{n}$-butanol and $0.1 \mathrm{~cm}^{3} \mathrm{dm}^{-3}$ triton-X-100 ${ }^{\circledR}$, at $30^{\circ} \mathrm{C}$ ) with different phosphate concentrations. Means (obtained from triplicate samples and represented as points on the graph) on a given line with the same letter are not different (Tukey test, $P<0.05)$.

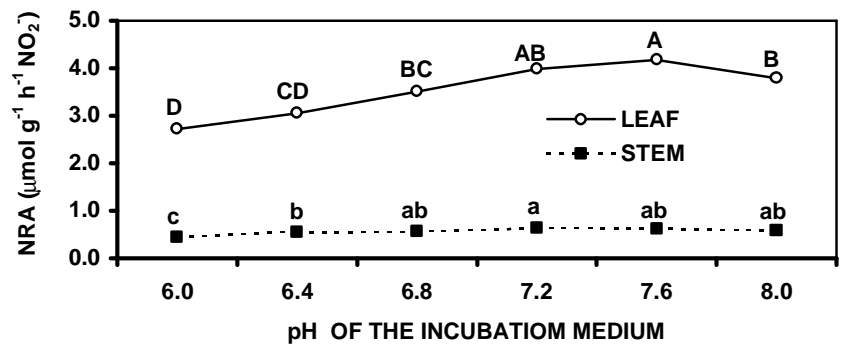

Figure 8 - Nitrate reductase activity (NRA) determined in leaf and stem tissues of Brachiaria radicans incubated for 80 minutes in media $\left(200 \mathrm{mmol} \mathrm{dm}^{-3}\right.$ phosphate buffer, 60 $\mathrm{mmol} \mathrm{dm} \mathrm{KNO}_{3}, 10 \mathrm{~cm}^{3} \mathrm{dm}^{-3} \mathrm{n}$-butanol and $0.1 \mathrm{~cm}^{3}$ $\mathrm{dm}^{-3}$ triton- $\mathrm{X}-100^{\circledR}$, at $30^{\circ} \mathrm{C}$ and vacuum infiltration), at different $\mathrm{pH}$ values. Means (obtained from triplicate samples and represented as points on the graph) for a given line with the same letter are not different (Tukey test, $P<0.05)$. 
Both $\mathrm{pH}$ and buffer isotonic strength are important variables in NRA determinations (Figures 7 and 8). Despite the stems having much lower levels of NRA compared to those of leaves, the stem tissue showed the highest activity at a lower $\mathrm{pH}$ and higher $\left[\mathrm{PO}_{4}^{-3}\right]$, and exhibited tolerance to a wider range of both $\mathrm{pH}$ or buffer strength.

The incubation of tissues under vacuum conditions enhanced $(P<0.05)$ NRA for leaves and stems by an average of $21 \%$ and $15 \%$, respectively, compared to the procedure without vacuum infiltration and incubation under room pressure (Figure 9). The assay showed a better performance after vacuum infiltration, with incubation

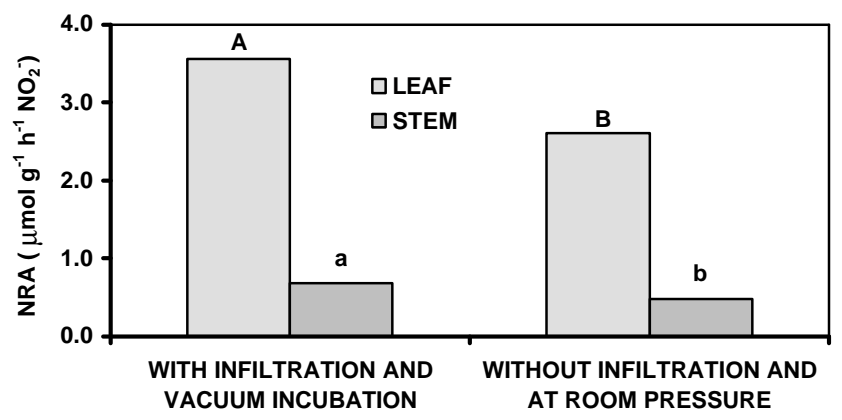

Figure 9 - Nitrate reductase activity (NRA) determined in leaf and stem tissues of Brachiaria radicans incubated for 80 minutes $\left(200 \mathrm{mmol} \mathrm{dm}^{-3}\right.$ phosphate buffer $\mathrm{pH} \mathrm{7.5,} 60$ mmol dm $\mathrm{KNO}_{3}, 10 \mathrm{~cm}^{3} \mathrm{dm}^{-3} \mathrm{n}$-butanol and $0.1 \mathrm{~cm}^{3}$ $\mathrm{dm}^{-3}$ triton-X-100 ${ }^{\circledR}$, at $\left.30^{\circ} \mathrm{C}\right)$ under vacuum $(85 \mathrm{kPa})$ after vacuum infiltration or at room pressure without previous vacuum infiltration. Means (obtained from triplicate samples and represented as bars on the graph) from a given tissue with the same letter are not different (Tukey test, $P<0.05$ ). maintained under vacuum conditions. Faleiros \& Cazetta (1996) suggested that this is probably due to the elimination of inter-cellular gases from the tissue, which improves the contact between solution and tissue. This causes the tissue to submerge into the medium. The removal of $\mathrm{O}_{2}$ from the tissue also reduces the possibility of $\mathrm{NO}_{2}^{-}$reduction to $\mathrm{NH}_{4}^{+}$in the cells, maintaining its diffusion towards the medium. Based on these results, the best in vivo assay to determine Brachiaria radicans NRA is the incubation of tissues in a medium composed of 200 mmol dm ${ }^{-3}$ phosphate buffer $\mathrm{pH} 7.4,60 \mathrm{mmol} \mathrm{dm} \mathrm{KNO}_{3}$, $10 \mathrm{~cm}^{3} \mathrm{dm}^{-3} \mathrm{n}$-butanol, and $0.1 \mathrm{~cm}^{3} \mathrm{dm}^{-3}$ triton-X-100 ${ }^{\oplus}$. This should be done under vacuum and in the dark for a period of time between 60 and 100 minutes.

When tanner grass was grown in pots, it produced 1.5 to 2.5 times more stem than leaf fresh weight (Table 1). However, the average NRA per unit of fresh weight was higher (from 4.6 to 10.5 fold) in leaves, compared to the stem tissue. When NRA in the whole plant was calculated, leaf tissue had an activity from 2.1 to 6.8 times greater than stem tissue.

The treatments did affect plant development and NRA of tanner grass tissues (Table 2). Except for leaf fresh weight and NRA per unit of stem fresh weight, there were no significant $\mathrm{N}$ source $\mathrm{x}$ Mo level interactions (Table 2), indicating that $\mathrm{N}$ sources and levels of Mo, under this soil and experimental conditions, tended to play independent roles.

Plants fertilized with $\mathrm{NaNO}_{3}$ and urea produced more leaf fresh weight than those fertilized with $\mathrm{NH}_{4} \mathrm{Cl}$ (Table 3). No differences, however, were observed for $\mathrm{N}$ sources on stem fresh weight. Nitrate fertilizer tended to

Table 1 - Fresh weight (FW) and nitrate reductase activity (NRA) in leaf and stem fresh tissues of Brachiaria radicans fertilized with $300 \mathrm{~kg} \mathrm{ha}^{-1} \mathrm{~N}$ as $\mathrm{NaNO}_{3}, \mathrm{NH}_{4} \mathrm{Cl}$, or urea, without Mo application or fertilized with $20 \mathrm{~kg} \mathrm{ha}^{-1} \mathrm{Mo}$ (as $\mathrm{H}_{2} \mathrm{Mo}_{2} \mathrm{O}_{4}$ ), plus two controls (no fertilization, and Mo only). The NRA determinations were carried out by incubating $200 \mathrm{mg}$ tissues for 80 minutes in medium containing $200 \mathrm{mmol} \mathrm{dm}^{-3}$ phosphate buffer $\mathrm{pH} 7.5,60 \mathrm{mmol} \mathrm{dm}^{-3} \mathrm{KNO}_{3}$, $10 \mathrm{~cm}^{3} \mathrm{dm}^{-3} \mathrm{n}$-butanol, and $0.1 \mathrm{~cm}^{3} \mathrm{dm}^{-3}$ triton-X-100 ${ }^{\circledR}$, at $30^{\circ} \mathrm{C}$, under vacuum $(85 \mathrm{kPa}$ ) following vacuum infiltration. The means in the table were obtained from three replications, and are accompanied by their standard deviation.

\begin{tabular}{|c|c|c|c|c|c|c|}
\hline \multirow{3}{*}{ Treatment } & \multicolumn{3}{|c|}{ Leaves } & \multicolumn{3}{|c|}{ Stems } \\
\hline & \multirow[t]{2}{*}{$\begin{array}{c}\text { Fresh } \\
\text { Weight }\end{array}$} & \multicolumn{2}{|c|}{ NRA } & \multirow[t]{2}{*}{$\begin{array}{c}\text { Fresh } \\
\text { Weight }\end{array}$} & \multicolumn{2}{|c|}{ NRA } \\
\hline & & $\begin{array}{c}\mu \text { mole of } \\
\mathrm{NO}_{2}^{-} \mathrm{h}^{-1} \mathrm{~g} \mathrm{FW}^{-1}\end{array}$ & $\begin{array}{c}\mu \text { mole of } \\
\mathrm{NO}_{2}^{-} \mathrm{h}^{-1} \text { plant }^{-1}\end{array}$ & & $\begin{array}{c}\mu \text { mole of } \\
\mathrm{NO}_{2}^{-} \mathrm{h}^{-1} \mathrm{gFW}^{-1}\end{array}$ & $\begin{array}{c}\mu \text { mole of } \\
\mathrm{NO}_{2}^{-} \mathrm{h}^{-1} \text { plant }^{-1}\end{array}$ \\
\hline & g plant ${ }^{-1}$ & & & g plant ${ }^{-1}$ & & \\
\hline No fertilization & $12.4 \pm 0.3$ & $0.94 \pm 0.22$ & $11.62 \pm 2.46$ & $27.34 \pm 1.70$ & $0.20 \pm 0.05$ & $5.52 \pm 1.20$ \\
\hline Only Mo & $11.7 \pm 1.4$ & $1.85 \pm 0.14$ & $21.58 \pm 3.29$ & $23.70 \pm 1.18$ & $0.39 \pm 0.08$ & $9.18 \pm 1.92$ \\
\hline $\mathrm{NaNO}_{3}$ & $21.2 \pm 3.2$ & $2.73 \pm 0.60$ & $57.89 \pm 17.39$ & $32.59 \pm 2.34$ & $0.26 \pm 0.04$ & $8.49 \pm 1.91$ \\
\hline $\mathrm{NH} 4 \mathrm{Cl}$ & $13.5 \pm 1.2$ & $1.71 \pm 0.52$ & $22.75 \pm 6.15$ & $27.83 \pm 1.58$ & $0.35 \pm 0.04$ & $9.74 \pm 1.24$ \\
\hline Urea & $18.7 \pm 1.6$ & $2.49 \pm 0.10$ & $46.65 \pm 5.69$ & $31.13 \pm 1.46$ & $0.29 \pm 0.02$ & $9.14 \pm 0.87$ \\
\hline $\mathrm{NaNO}_{3}+\mathrm{Mo}$ & $15.7 \pm 2.6$ & $3.21 \pm 0.62$ & $50.94 \pm 14.53$ & $28.72 \pm 4.49$ & $0.35 \pm 0.04$ & $10.16 \pm 2.19$ \\
\hline $\mathrm{NH}_{4} \mathrm{Cl}+\mathrm{Mo}$ & $12.6 \pm 0.1$ & $1.43 \pm 0.34$ & $17.97 \pm 4.32$ & $26.19 \pm 2.04$ & $0.24 \pm 0.05$ & $6.26 \pm 1.80$ \\
\hline Urea + Mo & $11.4 \pm 0.4$ & $1.91 \pm 0.85$ & $22.00 \pm 10.73$ & $28.57 \pm 3.07$ & $0.28 \pm 0.05$ & $8.11 \pm 2.30$ \\
\hline
\end{tabular}

Sci. Agric. (Piracicaba, Braz.), v.61, n.6, p.640-648, Nov./Dec. 2004 
induce higher NRA in the leaf tissue when compared to $\mathrm{NH}_{4} \mathrm{Cl}$ and urea. The ammonium fertilizer induced slower shoot development, when compared to $\mathrm{NaNO}_{3}$ (Table 3), suggesting that tanner grass cannot detoxify $\mathrm{NH}_{4}^{+}$, as reported for other species (Roberts \& Menary, 1994).

Plants fertilized with urea tended to show intermediate growth and NRA values, despite visual similarities between $\mathrm{NaNO}_{3}$ or $\mathrm{NH}_{4} \mathrm{Cl}$ fertilized plants (Table 3). Despite the fact that urea is a source of $\mathrm{NH}_{4}^{+}$, not all of it is immediately available, but is slowly released during its hydrolysis in the soil. The rate of urea hydrolysis in soils containing low levels of organic matter (like the one used in this research) tends to be low (Reynolds et al., 1985). Thus, $\mathrm{NH}_{4}^{+}$is released at such a rate that the plant can absorb $\mathrm{NH}_{4}^{+}$with little risk of toxicity. Also, in the moisture and oxidizing conditions under which the soil was maintained in this study, $\mathrm{NH}_{4}^{+}$was probably slowly oxidized to $\mathrm{NO}_{3}^{-}$(Malavolta, 1981), providing a $\mathrm{NO}_{3}^{-}$supply just enough to induce a slight NRA increase (Kawachi et al., 2002).

Table 2 - Analysis of variance and $\mathrm{F}$ test results obtained for fresh weight and nitrate reductase activity (NRA) in leaf and stem fresh weight (FW) tissues of Brachiaria radicans fertilized with $300 \mathrm{~kg} \mathrm{ha}^{-1} \mathrm{~N}$ as $\mathrm{NaNO}_{3}, \mathrm{NH}_{4} \mathrm{Cl}$, or urea, without Mo application or fertilized with $20 \mathrm{~kg} \mathrm{ha}^{-1} \mathrm{Mo}\left(\mathrm{as} \mathrm{H}_{2} \mathrm{Mo}_{2} \mathrm{O}_{4}\right)$, plus two controls (No fertilization, and Mo only).

\begin{tabular}{|c|c|c|c|c|c|c|c|}
\hline \multirow{3}{*}{$\begin{array}{l}\text { Causes of } \\
\text { Variations }\end{array}$} & \multirow{3}{*}{$\begin{array}{l}\text { Degrees of } \\
\text { freedom }\end{array}$} & \multicolumn{3}{|c|}{ Leaves } & \multicolumn{3}{|c|}{ Stems } \\
\hline & & \multirow[t]{2}{*}{$\begin{array}{c}\text { Fresh } \\
\text { weight }\end{array}$} & \multicolumn{2}{|c|}{ NRA } & \multirow[t]{2}{*}{$\begin{array}{c}\text { Fresh } \\
\text { weight }\end{array}$} & \multicolumn{2}{|c|}{ NRA } \\
\hline & & & $\begin{array}{c}\mu \text { mole of } \\
\mathrm{NO}_{2}^{-} \mathrm{h}^{-1} \mathrm{~g} \mathrm{FW}^{-1}\end{array}$ & $\begin{array}{c}\mu \text { mole of } \\
\mathrm{NO}_{2}^{-} \mathrm{h}^{-1} \text { plant }^{-1}\end{array}$ & & $\begin{array}{c}\mu \text { mole of } \\
\mathrm{NO}_{2}^{-} \mathrm{h}^{-1} \mathrm{~g} \mathrm{FW}^{-1}\end{array}$ & $\begin{array}{c}\mu \text { mole of } \\
\mathrm{NO}_{2}^{-} \mathrm{h}^{-1} \text { plant }^{-1}\end{array}$ \\
\hline & & g plant $^{-1}$ & & & g plant $^{-1}$ & & \\
\hline Treatments & (7) & $12.91 * *$ & $6.71 * *$ & $10.02 * *$ & $3.79 *$ & $5.07 * *$ & $2.67 *$ \\
\hline Control $\times$ Factorial & 1 & $18.39 * *$ & $13.40 * *$ & $19.15 * *$ & $9.95 * *$ & $0.01^{\mathrm{NS}}$ & $2.49^{\mathrm{NS}}$ \\
\hline Between controls & 1 & $0.26^{\mathrm{NS}}$ & $5.12 *$ & $3.62 *$ & $3.28 *$ & $21.40 * *$ & $6.59 *$ \\
\hline Source of N (A) & 2 & $14.94 * *$ & $12.21 * *$ & $19.15 * *$ & $3.60 *$ & $0.23^{\mathrm{NS}}$ & $0.87^{\mathrm{NS}}$ \\
\hline Level of Mo (B) & 1 & $31.13 * *$ & $0.29^{\mathrm{NS}}$ & $7.21 *$ & $5.40 *$ & $0.22^{\mathrm{NS}}$ & $1.35^{\mathrm{NS}}$ \\
\hline Interaction (A x B) & 2 & $5.34 *$ & $1.87^{\mathrm{NS}}$ & $1.94^{\mathrm{NS}}$ & $0.31^{\mathrm{NS}}$ & $6.69 * *$ & $3.25^{\mathrm{NS}}$ \\
\hline Error & 16 & - & - & - & - & - & - \\
\hline Total & $(23)$ & - & - & - & - & - & - \\
\hline Coef. of variation & - & $11.82 \%$ & $24.19 \%$ & $30.49 \%$ & $8.69 \%$ & $16.45 \%$ & $20.97 \%$ \\
\hline
\end{tabular}

**F test significant at $P<0.01 ; * \mathrm{~F}$ test significant at $P<0.05 ;{ }^{\mathrm{NS}} \mathrm{F}$ test not significant $(P>0.05)$.

Table 3 - Main effects of sources of nitrogen, levels of Mo, and controls on the fresh weight (FW) and nitrate reductase activity (NRA) of leaf and stem tissues of Brachiaria radicans fertilized with $300 \mathrm{~kg} \mathrm{ha}^{-1}$ of $\mathrm{N}$ as $\mathrm{NaNO}_{3}, \mathrm{NH}_{4} \mathrm{Cl}$, or urea, without Mo application or fertilized with $20 \mathrm{~kg} \mathrm{ha}^{-1} \mathrm{Mo}\left(\mathrm{as}_{2} \mathrm{Mo}_{2} \mathrm{O}_{4}\right)$, plus two controls (No fertilization, and Mo only), obtained from a factorial statistical analysis.

\begin{tabular}{|c|c|c|c|c|c|c|c|}
\hline \multirow{3}{*}{\multicolumn{2}{|c|}{ Factors / Treatments }} & \multicolumn{3}{|c|}{ Leaves \# } & \multicolumn{3}{|c|}{ Stems \# } \\
\hline & & \multirow{2}{*}{$\begin{array}{l}\text { Fresh } \\
\text { weight }\end{array}$} & \multicolumn{2}{|c|}{ NRA } & \multirow{2}{*}{$\begin{array}{l}\text { Fresh } \\
\text { weight }\end{array}$} & \multicolumn{2}{|c|}{ NRA } \\
\hline & & & $\begin{array}{c}\mu \text { mole of } \\
\mathrm{NO}_{2}^{-} \mathrm{h}^{-1} \mathrm{~g} \mathrm{FW}^{-1}\end{array}$ & \begin{tabular}{c}
\multicolumn{2}{c}{$\mu$ mole of } \\
$\mathrm{NO}_{2}^{-} \mathrm{h}^{-1}$ plant $^{-1}$
\end{tabular} & & $\begin{array}{c}\mu \text { mole of } \\
\mathrm{NO}_{2}^{-} \mathrm{h}^{-1} \mathrm{~g} \mathrm{FW}^{-1}\end{array}$ & $\begin{array}{c}\mu \text { mole of } \\
\mathrm{NO}_{2}^{-} \mathrm{h}^{-1} \text { plant }^{-1}\end{array}$ \\
\hline & & g plant ${ }^{-1}$ & & & g plant $^{-1}$ & & \\
\hline \multirow{3}{*}{$\begin{array}{l}\text { Source of } \\
\text { nitrogen }\end{array}$} & $\mathrm{NaNO}_{3}$ & $18.43 \mathrm{~A}$ & $2.968 \mathrm{~A}$ & $54.415 \mathrm{~A}$ & $30.66 \mathrm{~A}$ & $0.306 \mathrm{~A}$ & $9.327 \mathrm{~A}$ \\
\hline & $\mathrm{NH}_{4} \mathrm{Cl}$ & $13.03 \mathrm{~B}$ & $1.568 \mathrm{~B}$ & $20.362 \mathrm{C}$ & $27.01 \mathrm{~A}$ & $0.294 \mathrm{~A}$ & $8.001 \mathrm{~A}$ \\
\hline & Urea & $15.07 \mathrm{~A}$ & $2.197 \mathrm{~B}$ & $34.326 \mathrm{~B}$ & $29.85 \mathrm{~A}$ & $0.287 \mathrm{~A}$ & $8.625 \mathrm{~A}$ \\
\hline \multirow{2}{*}{ Level of Mo } & $0 \mathrm{~kg} \mathrm{ha}^{-1}$ & $17.79 \mathrm{a}$ & $2.307 \mathrm{a}$ & $42.432 \mathrm{a}$ & $30.51 \mathrm{a}$ & $0.301 \mathrm{a}$ & $9.129 \mathrm{a}$ \\
\hline & $20 \mathrm{~kg} \mathrm{ha}^{-1}$ & $13.24 \mathrm{~b}$ & $2.182 \mathrm{a}$ & $30.304 \mathrm{~b}$ & $27.83 \mathrm{~b}$ & $0.290 \mathrm{a}$ & $8.173 \mathrm{a}$ \\
\hline \multirow{2}{*}{ Controls } & No fertilization & $12.38 \mathrm{~A}$ & $0.941 B$ & $11.62 B$ & $27.34 A$ & $0.204 B$ & $5.522 B$ \\
\hline & Only Mo & $11.65 \mathrm{~A}$ & $1.850 \mathrm{~A}$ & $21.58 A$ & $23.70 \mathrm{~A}$ & $0.387 A$ & $9.183 A$ \\
\hline
\end{tabular}

\#Values were obtained from three replications. Means followed by the same letter within each factor and variable are not different (Tukey test, $P>0.05)$. 
When Mo was added, plant development (leaf and stem fresh weight) was partially suppressed, as well as total NRA in leaf tissue. NRA in stem tissue showed no differences $(P<0.05)$, but data suggested a similar pattern as that observed for leaves (Tables 1, 2, and 3). The growth suppression imposed by Mo application may be due to partial toxicity. No injury symptoms were observed in the plants used in this study, although Gupta (2001) stated that symptoms become apparent only under very high Mo levels.

When Mo was applied in the absence of $\mathrm{N}$ (control), it improved NRA, but stalk development tended to be suppressed (Tables 2 and 3). Leaf fresh weigh tended to show similar results, although the differences did not reach significant levels $(P<0.05)$ (Tables 2 and 3$)$. It seems that Mo improved NRA because it is a NR cofactor; however, the rate of Mo applied to the soil in this research probably was too high for this species, and may explain the partial suppression of plant development.

The addition of Mo tended to reduce leaf fresh weight of plants under $\mathrm{NaNO}_{3}$ and urea fertilization (Tables 2 and 4). Also, urea promoted better leaf growth than $\mathrm{NH}_{4} \mathrm{Cl}$ when Mo was not applied, but did not differ under Mo fertilization (Table 4). Sources of N did not affect stem NRA when plants were grown without Mo fertilization (Table 5). However, for Mo fertilized plants, $\mathrm{NaNO}_{3}$ induced higher NRA when compared to $\mathrm{NH}_{4} \mathrm{Cl}$, while urea produced intermediate values. On the other hand, the effect on NRA was increased by $\mathrm{NaNO}_{3}$, decreased by $\mathrm{NH}_{4} \mathrm{Cl}$, and was not altered by urea under $\mathrm{Mo}$ fertilization.

These findings together suggest that in this research the limitation imposed by Mo application would not be directly related to NR, but involved toxicity in other ways.

In summary, the objective of the NRA assay optimization was met. Tanner grass plants produced much more stem fresh weight than leaf fresh weight, with most NRA found in the leaves. Although it would be expected that, to some extent, tanner grass plants could avoid $\mathrm{NO}_{3}{ }^{-}$ reduction by absorbing reduced $\mathrm{N}$ directly from fertilizers, $\mathrm{NH}_{4} \mathrm{Cl}$ and urea induced less plant development when compared to $\mathrm{NaNO}_{3}$, showing that this species has a lower tolerance to these sources of $\mathrm{N}$, mainly $\mathrm{NH}_{4} \mathrm{Cl}$. The application of $20 \mathrm{~kg} \mathrm{ha}^{-1}$ of $\mathrm{Mo}$ as $\mathrm{H}_{2} \mathrm{Mo}_{2} \mathrm{O}_{4}$ to the soil under the conditions used in this research, affected plant development and NRA to some extent; however, it seems that the reduced plant growth observed did not directly involve NRA.

Further research is needed to unveil the plant toxicity mechanism triggered by high levels of Mo in the soil, and how it effects $\mathrm{N}$ utilization. Experiments consisting of combinations of different $\mathrm{NO}_{3}{ }^{-}$and Mo levels might help clarify and better understand this matter.
Table 4 - Effects of the interaction between sources of $\mathrm{N}$ and levels of Mo on leaf fresh weight $\left(\mathrm{g} \mathrm{plant}^{-1}\right)$ of Brachiaria radicans fertilized with $300 \mathrm{~kg} \mathrm{ha}^{-1}$ of $\mathrm{N}$ as $\mathrm{NaNO}_{3}, \mathrm{NH}_{4} \mathrm{Cl}$, or urea, without Mo application or fertilized with $20 \mathrm{~kg} \mathrm{ha}^{-1}$ Mo (as $\mathrm{H}_{2} \mathrm{Mo}_{2} \mathrm{O}_{4}$ ), obtained from a factorial statistical analysis.

\begin{tabular}{|c|c|c|c|}
\hline \multirow{2}{*}{ Level of Mo } & \multicolumn{3}{|c|}{ Sources of N } \\
\hline & $\mathrm{NaNO}_{3}$ & $\mathrm{NH}_{4} \mathrm{Cl}$ & Urea \\
\hline $\mathrm{kg} \mathrm{ha}^{-1}$ & \multicolumn{3}{|c|}{ - } \\
\hline 0 & A $21.15 \mathrm{a} *$ & A $13.50 \mathrm{~b}$ & A $18.71 \mathrm{a}$ \\
\hline 20 & B $15.72 \mathrm{a}$ & A $12.56 \mathrm{ab}$ & B $11.43 \mathrm{~b}$ \\
\hline
\end{tabular}

*Capital letters compare means within each column and small letters within each line. Means followed by the same letter are not different (Tukey test, $P>0.05$ ).

Table 5 - Effects of the interaction between sources of $\mathrm{N}$ and levels of Mo on stem nitrate reductase activity $\left(\mu\right.$ mole $\mathrm{h}^{-1} \mathrm{gFW}^{-1}$ $\mathrm{NO}_{2}^{-}$) of Brachiaria radicans fertilized with $300 \mathrm{~kg} \mathrm{ha}^{-1}$ of $\mathrm{N}$ as $\mathrm{NaNO}_{3}, \mathrm{NH}_{4} \mathrm{Cl}$ or urea, without Mo application or fertilized with $20 \mathrm{~kg} \mathrm{ha}^{-1} \mathrm{Mo}\left(\mathrm{as}_{2} \mathrm{Mo}_{2} \mathrm{O}_{4}\right.$ ), obtained from a factorial statistical analysis.

\begin{tabular}{|c|c|c|c|}
\hline \multirow{2}{*}{ Level of Mo } & \multicolumn{3}{|c|}{ Sources of $\mathrm{N}$} \\
\hline & $\mathrm{NaNO}_{3}$ & $\mathrm{NH}_{4} \mathrm{Cl}$ & Urea \\
\hline $\mathrm{kg} \mathrm{ha}^{-1}$ & \multicolumn{3}{|c|}{ - } \\
\hline 0 & B $0.259 \mathrm{a} *$ & A 0.350 a & A $0.294 \mathrm{a}$ \\
\hline 20 & A $0.353 \mathrm{a}$ & B $0.238 \mathrm{~b}$ & A $0.280 \mathrm{ab}$ \\
\hline
\end{tabular}

*Capital letters compare means within each column and small letters within each line. Means followed by at least one identical letter are not different (Tukey test, $P>0.05$ ).

\section{ACKNOWLEDGEMENTS}

This study was supported in part by a scholarship awarded to L.C.V. Villela by FAPESP.

\section{REFERENCES}

ASLAM, M.; HUKFFAKER, R.C.; RAINS, D.W. Early effects of salinity on nitrate assimilation in barley seedlings. Plant Physiology, v.76, p.321325, 1984.

BAER, G.R.; COLLET, G.F. In vivo determination of parameters of nitrate utilization in wheat (Triticum aestivum L.) seedling grown with low concentration of nitrate in the nutrient solution. Plant Physiology, v.68, p.1237-1243, 1981.

BARTHES, L.; DELEENS, E.; BOUSSER, A.; HOARAU, J.; PRIOL, J.L. Xylem exudation is related to nitrate assimilation pathway in developing maize seedlings: Use of nitrate reductase and glutamine synthetase inhibitors as tools. Journal of Experimental Botany, v.47, p.485-495, 1996.

BLONDEL, A.M.; BLANC, D. Mise au point dúne methode de mesure in vivo de lactivité de la nitrate reductase. Annals of Agronomy, v.26, p.309-322, 1975.

BRUNETTI, N.; HAGEMAN, R.H. Comparison of in vivo and in vitro assays of nitrate reductase in wheat (Triticum aestivum L.) seedlings. Plant Physiology, v.58, p.583-587, 1976.

DORDAS, C.; SAH, R.; BROWN, P.H.; ZENG, Q.; HU, H. Remobilização de micronutrientes e elementos tóxicos em plantas superiores. In: FERREIRA, M.E.; CRUZ, M.C.P.; RAIJ, B.V.; ABREU, C.A. (Ed.) Micronutrientes e elementos tóxicos na agricultura. Jaboticabal: CNPq; FAPESP; Potafos, 2001. cap.3, p.43-61. 
FALEIROS, R.R.S.; CAZETTA, J.O. Optimization of the in vivo assay for nitrate reductase activity determination in pigeon pea [Cajanus cajan (L.) Millsp] leaves. Científica, v.24, p.385-396, 1996.

GUPTA, U.C. Micronutrientes e elementos tóxicos em plantas e animais. In: FERREIRA, M.E.; CRUZ, M.C.P.; RAIJ, B.V.; ABREU, C.A. (Ed.) Micronutrientes e elementos tóxicos na agricultura. Jaboticabal: CNPq; FAPESP; Potafos, 2001. cap.2, p.13-42.

HARPER, J.E. Evolution of nitrogen oxide(s) during in vivo nitrate reductase assay of soybean leaves. Plant Physiology, v.68, p.1488-1493, 1981.

HEUER, B.; PLAUT, Z. Reassessment of the in vivo assay for nitrate reductase in leaves. Physiologia Plantarum, v.43, p.306-312, 1978.

JAWORSKI, E.K. Nitrate reductase assay in intact plant tissues. Biochemical and Biophysical Research Communications, v.43, p.1274-1279, 1971.

JONES, R.W.; SHEARD, R.W. Conditions affecting in vivo nitrate reductase activity in chlorophyllous tissues. Canadian Journal of Botany, v.55, p.896-901, 1977.

KAWACHI, T.; SHOJI, Y.; SUGIMOTO, T.; OJI, Y.L.; KLEINHOFS, A.; WARNER, R.L.; OHTAKE, N.; OHYAMA, T.; SUEIOSHI, K. Role of xylem sap nitrate in regulation of nitrate reductase gene expression in leaves of barley (Hordeum vulgare L.) seedlings. Soil Science and Plant Nutrition, v.48, p.79-85, 2002.

KLEPPER, L.; FLESHER, D.; HAGEMAN, R.H. Generation of reduced Nicotinamide Adenine Dinucleotide for nitrate reduction in green leaves. Plant Physiology, v.48, p.580-590, 1971.

LAWRENCE, J.M.; HERRICK, H.E. Media for in vivo nitrate reductase assay of plant tissues. Plant Science Letters, v.24, p.17-26, 1982.

LEA, P.J. Primary nitrogen metabolism. In: DAY, P.M.; J.B. HARBORN (Ed.) Plant biochemistry. New York: Academic Press, 1997. cap.7, p.273-313.

LILLO, C. Studies of diurnal variations of nitrate reductase activity in barley leaves using various assay methods. Physiologia Plantarum, v.57, p.357-362, 1983.

LIN, W.H.; KAO, C.H. Factors affecting nitrate reductase activity in triticale. Physiologia Plantarum, v.48, p.361-364, 1980.

MALAVOLTA, E. Elementos de nutrição mineral de plantas. São Paulo: Ed. Agronômica Ceres, 1981.

MITIDIERI, J. Manual de gramíneas e leguminosas para pastos tropicais. São Paulo: EDUSP, 1983.

MULLER, E.K.H.; JANIESHCH, P. In vivo nitrate reductase activity in Carex pseudocyperus L.: the influence of nitrate-ammonium concentration ratios and correlation with growth. Journal of Plant Nutrition, v.16, p.1357-1372, 1993
NICHOLAS, J.C.; HARPER, J.E.; HAGEMAN, R.H. Nitrate reductase activity in soybeans (Glycine max [L] Merr.): 1. Effects of light and temperature. Plant Physiology, v.58, p.731-735, 1976.

PURANIK, R.M.; SRIVASTAVA, H.S. Increase in nitrate reductase activity in the presence of sucrose in bean leaf segments. Phytochemistry, v.22, p.2383-2387, 1983

REYNOLDS, C.M.; WOLF, D.C.; ARMBRUSTER, J.A. Factors related to urea hydrolysis in soils. Soil Science Society of America Journal, v.49, p.104-108, 1985.

ROBERTS, N.J.; MENARY, R.C. Effect of nitrogen on growth, flower yield, oil composition, and yield in Boronia megastigma Nees. Journal of Plant Nutrition, v.17, p.2035-2052, 1994.

SKERMAN, P.J.; RIVEROS, F. Tropical grasses. Rome: FAO, 1990. 254p. (FAO (Plant Production and Protection Series, 23).

STITT, M.; MÜLlER, C.; MATT, P.; GIBSON, Y.; CARILlO, P.; MORCUENDE, R.; SCHEIBLE, W.; KRAPP, A. Steps towards an integrated view of nitrogen metabolism. Journal of Experimental Botany, v.53, p.959-970, 2002.

SOUZA, F.H.D. Brachiaria spp in Brazil. In: LOCH, D.S.; FERGUSSON, J.E. (Ed.) Forage seed production: tropical and subtropical species. New York: CAB International Publishing, 1999. v.2, p.371-379.

SRIVASTAVA, H.S. Regulation of nitrate reductase activity in higher plants. Phytochemistry, v.19, p.725-733, 1990.

STOLTZ, J.F.; BAZU, P. Evolution of nitrate reductase: Molecular and structural variations on a common function. Chembiochem, v.3, p.198206, 2002.

STREETER, J.G.; BOSLER, M.E. Comparison of in vitro and in vivo assays for nitrate reductase in soybeans leaves. Plant Physiology, v.49, p.448$450,1972$.

TINGEY, D.T.; FITES, R.C.; BAHARSJAH, J. Factors influencing nitrate reductase in soybean foliage. New Phytologyst, v.73, p.21-29, 1974.

VIÉGAS, R.A.; MELLO, A.R.B.; SILVEIRA, J.A.G. Nitrate reductase activity and proline accumulation in cashew in response to $\mathrm{NaCl}$ salt shock. Revista Brasileira de Fisiologia Vegetal, v.11, p.21-28, 1999.

WATANABE, M.; HAYASHI, M.; SUGIYAMA, T. Effects of supplemental nitrate application on the activity of some nitrogen assimilation enzymes and leaf tissue productivity in maize seedlings. Soil Science and Plant Nutrition, v.31, p.573-580, 1985.

Received Fevruary 14, 2003

Accepted September 13, 2004 